\title{
Willingness to Pay for Chicks of Different Indigenous Chicken Types: An Application of Experimental Auctions
}

\author{
M.N.D.F. Abeykoon ${ }^{*}$, J. Weerahewa ${ }^{1}$, P. Weligamage ${ }^{1}$ and G.L.L.P. Silva ${ }^{2}$ \\ Postgraduate Institute of Agriculture \\ University of Peradeniya \\ Sri Lanka
}

\begin{abstract}
Backyard poultry production continues to remain as a sustainable production system in rural areas with $15 \%$ contribution to national egg production. Farmers rear locally well-adapted indigenous chicken with low external inputs. Lack of supply of chicks is a main limitation to expand this subsector. Understanding the nature of demand for different types of indigenous chicks is important to plan interventions for continuous operation and future expansions. Also production and market information of chicken help farmers to make decision in chicken rearing. This study was conducted with objectives of a) to determine the willingness to pay (WTP) by farmers for chicks of different types of indigenous chicken, $b$ ) to determine the effect of information on bidding behaviour and, $c$ ) to determine the factors that influence the WTP for chicken. A series of experimental auctions were conducted with the participation of 45 and 94 farmers in Thirappane of the North Central Province and Karuwalagaswewa of the North Western Province, respectively. Random nth price auction method was used to collect data. Data were analyzed using ANOVA, t-tests and Tobit regression. The results of one-way ANOVA indicated that there are significant differences among the bids for chicks of different chicken types. Results of paired t-test showed that mean bids have increased after exposure to production and market information except for commercial layers. Tobit regression results revealed that the farmers' WTP for chicks is significantly influenced by age of the bidder, market segmentation by chicken type, bidding round (with and without information) and the type of primary livelihood activity of the bidders. The findings indicated that the potential of developing indigenous chicks market is differentiated by the type of chicken.
\end{abstract}

Keywords: Backyard poultry farming, indigenous chicken, input demand determinants, sustainable farming systems, willingness to pay

\section{INTRODUCTION}

Poultry production systems in Sri Lanka are ranged from backyard production to intensive systems. In intensive systems, exotic birds are reared under high input management with intense use of capital and labour. Further, this is a market oriented system. Conversely, backyard production is characterized by indigenous stocks being allowed to roam freely and scavenge for their feed. It's a low risk-low investment-low production-low return enterprise system with extensive form of management. In Sri Lanka, the commercial intensive

\footnotetext{
1 Department of Agricultural Economics and Business Management, Faculty of Agriculture, University of Peradeniya, Sri Lanka

2 Department of Animal Science, Faculty of Agriculture, University of Peradeniya, Sri Lanka

Corresponding author: niru04307@yahoo.com
} 
production has increased and the backyard production has reduced in the recent past. However, backyard poultry production systems still remain in rural areas of the country as a way to fulfil family nutrition requirements and additional income source. This low input-low output production system is very sustainable for resource poor farmers (Mlozi et al., 2003; Gondwe and Wollny, 2007). They have a multitude of roles such as food, income generation and culturalrites (Scoones, 1992; Das et al., 2008).

Indigenous chickens are rated to have superior merits with regard to traits such as tolerance to disease and harsh environment, ability to escape from predators, scavenging, and broody behaviours and hatchability of eggs which are important in adaptation to the village environment. In addition, they are valued for traits, such as taste of egg and meat, affecting consumption preference and consequently the market value. The potential of backyard poultry as a source of nutrition and a source of income for rural farmers has not been fully exploited. Thus, it is important to investigate the reasons and constraints behind not emerging the backyard poultry sector as an economically profitable industry to uplift the livelihood of resource poor farmers in rural areas in Sri Lanka.

According to previous studies limitations in inputs such as land, feed and breeding stocks were the main drawbacks in backyard poultry sector in Sri Lanka (Baseline survey report FAnGR Asia, 2011). Moreover, the market of indigenous chicken is still under developed including the market of adult live birds and chicks. Hence, developing the chicks market is important to improve the backyard poultry sector where the first step has to be the investigation of market potential for chicks of indigenous chicken and the preference of farmers. Also, due to lack of production and market information, farmers are unable to make correct decisions on the suitable chicken rearing systems for them. It will be easier for farmers to take decisions if they could be aware on the advantages and disadvantages of commercial and backyard poultry rearing, costs and benefits of each systems, and market prices. Therefore, the objectives of this study were (1) To determine the farmers' willingness to pay (WTP) for chicks of different indigenous chicken types (2) To determine the effect of information on bidding behaviour and (3) To determine the factors that influence the willingness to pay for chicken.

Market prices serve as the basis in economic valuation of the goods and services that are available in the market. But non-market valuation techniques are applied for the goods and services where market prices do not exist. There is no existing market for indigenous chicks differentiated by the type of chicken. Therefore, non-market valuation technique was required in this study to determine the WTP for indigenous chicks.

\section{METHODOLOGY}

\section{Nonmarket valuation techniques and experimental auctions}

A large number of nonmarket valuation techniques are available to measure consumer willingness to pay, mainly including the stated preference methods and revealed preference methods. The revealed preference methods can be used to value existing goods and services only because the method is based on actual behaviour of individuals. Hedonic pricing and travel cost methods are the widely used revealed preference methods. Conjoint analysis, choice experiments and contingent valuation are the most popular stated preference methods. The main drawback in stated preference methods is that it is not incentive compatible due to the hypothetical setup and the fact that no actual behaviour is observed. 
Economic experiments were developed combining advantages of stated and revealed preference methods while avoiding the weaknesses in those methods. At present experimental economics, especially the experimental auctions play an important role as a valuable tool in market research. It has become very useful in nonmarket valuation because of perceived benefits relative to traditional methods. Since real products and real money are exchanged in an experimental setting, participants have more incentive to reveal their true values for a product than in a hypothetical survey setting (Lusk and Shogren, 2007). Moreover, experiments make active market environment where participants can learn and adjust to market condition. However, experimental auctions also have some limitations. Once an only limited number of participants can take part in the auction and it takes some time for participants to understand the auction mechanism.

Different auction mechanisms have been employed to elicit WTP in previous studies such as Vickerey second price, Random $n$th price, English, BDM auctions etc. The mechanism of each auction type is given in Table 1.

Table 1. Incentive compatible auctions

\begin{tabular}{|c|c|c|c|c|}
\hline \multicolumn{5}{|c|}{ Auction types } \\
\hline & Second price & $\begin{array}{l}\text { Random } n^{\text {th }} \\
\text { Price }\end{array}$ & English & BDM \\
\hline $\begin{array}{l}\text { Participant } \\
\text { procedure }\end{array}$ & $\begin{array}{l}\text { Simultaneously } \\
\text { submit sealed } \\
\text { bids }\end{array}$ & $\begin{array}{l}\text { Simultaneously } \\
\text { submit sealed bids }\end{array}$ & $\begin{array}{l}\text { Sequentially } \\
\text { offer } \\
\text { ascending bids }\end{array}$ & $\begin{array}{l}\text { Simultaneously } \\
\text { submit sealed } \\
\text { bids }\end{array}$ \\
\hline $\begin{array}{l}\text { Winning } \\
\text { bidder }\end{array}$ & $\begin{array}{l}\text { Participant with } \\
\text { highest bid }\end{array}$ & $\begin{array}{l}\text { All participants } \\
\text { with bid greater } \\
\text { than a randomly } \\
\text { drawn (nth)bid }\end{array}$ & $\begin{array}{l}\text { Participant who } \\
\text { offers the last bid }\end{array}$ & $\begin{array}{l}\text { All participants } \\
\text { with bid greater } \\
\text { than a randomly } \\
\text { drawn price }\end{array}$ \\
\hline $\begin{array}{l}\text { Number of } \\
\text { winners }\end{array}$ & 1 & $n-1$ & 1 & $\begin{array}{l}0 \text { to all } \\
\text { participants }\end{array}$ \\
\hline $\begin{array}{l}\text { Market } \\
\text { price }\end{array}$ & $\begin{array}{l}\text { Second highest } \\
\text { bid }\end{array}$ & $n$th highest bid & Last bid offered & $\begin{array}{l}\text { Randomly } \\
\text { drawn price }\end{array}$ \\
\hline $\begin{array}{l}\text { Market } \\
\text { feedback? }\end{array}$ & $\begin{array}{l}\text { Yes, with } \\
\text { multiple rounds }\end{array}$ & $\begin{array}{l}\text { Yes, with multiple } \\
\text { rounds }\end{array}$ & Yes & No \\
\hline References & Vickrey, 1961 & $\begin{array}{l}\text { Shogren et al., } \\
2001\end{array}$ & $\begin{array}{l}\text { Coppinger et al., } \\
1980\end{array}$ & $\begin{array}{l}\text { Becker et al., } \\
1964\end{array}$ \\
\hline
\end{tabular}

In English auction, the auctioneer opens the auction at a relatively lower price. Then competitors raise their bids until only one participant is willing to pay the current price and that person wins the auction and buy the good at the last price offered. In all the other auctions sealed bids are simultaneously submitted by the participants. In second price auction, individual with highest bid wins the auction but he/she only pay the second highest 
bid amount. This mechanism is relatively simple, demand revealing and has an endogenous market clearing price, but it does not include off margin bidders. In BDM mechanism, a random price is drawn from a predetermined distribution of prices. Participants that bid greater than the randomly drawn price win the auction and purchase good at the randomly drawn price. This is also a demand revealing method but the price is not determined endogenously.

In Random $n$th price auction method, one bid (the $n$th bid) is drawn from the sample and individuals with bids greater than the $n$th bid win the auction and buy the good at the $n$th price. In this method, everyone has an equal chance to win because market price is determined randomly and endogenously. Random $n$th price auction theoretically combines the best features of second price and BDM auction. Also it is demand revealing, incentive compatible and encourages sincere bidding. Therefore, random $n$th price auction mechanism was employed in this study.

\section{Study area}

The study was conducted in two selected sites namely: Thirappane (Site 1) and Karuwalagaswewa (Site 2) veterinary divisions which are located in Anuradhapura district and Puttalam district, respectively. Labunoruwa and Alagollawa were the two selected villages in Site 1. The two selected villages of Site 2 were Thabbowa, and Thewanuwara. The study areas were selected based on the availability of indigenous chicken and their diversity. In the preliminary investigations these two areas were identified as main areas with high indigenous chicken population in the country.

\section{The participants}

Two Auctions were held with one per site. Open invitation was made for all the farmers who were engaged in backyard poultry in selected villages to participate in the auctions. 45 and 94 farmers participated from Thirappane and Karuwalagaswewa sites, respectively.

\section{Experimental auction design}

The following fourteen steps were involved in the conduct of experimental auction.

a) Farmers who engaged in backyard poultry rearing in the selected villages were invited to participate in the auction.

b) Participants were asked to fill pre-auction survey on their arrival at the auction site, in order to gather demographic data

c) Live birds those represent different chicken types were displayed in cages.

- Cage A - Commercial layer

- Cage B - Normal village chicken

- Cage C - Naked neck chicken

- Cage D - Frizzled feathered chicken

- Cage E - Crown chicken

d) The participants were divided into four groups. 
e) Random identification numbers were given to all the participants.

f) Bidding instructions were explained to participants (Instructions are listed in appendix A).

g) Trial session was conducted for participants to get familiarized with the auction mechanism using a plate of sweets.

h) Then each group was given two chicken types for bidding. Breed A (Commercial layer) was kept as the reference breed where every group place their bids for breed A and a assigned indigenous chicken type as shown in the Table 2 .

Table2. Chicken types assigned for different groups

\begin{tabular}{cc}
\hline Group & Chicken types given for bidding \\
\hline I & A and B \\
II & A and C \\
III & A and D \\
IV & A and E \\
\hline
\end{tabular}

i) Bidding round 1: Participants in each group was asked to place their individual bids (how much they are willing to pay) for 2 months old chicks of the two chicken types separately.

j) Then the bids of each group were collected separately for chicken types and they were sorted from the highest to the lowest bid. After that for each chicken type, one bid was randomly drawn to determine the payment price of the round.

k) Everyone who bid higher than the payment prices were taken as the winners of the bidding round.

1) The identification numbers of all the winners and the payment prices were revealed.

m) Then the production and market information about those chicken types were given (Appendix B) and re-conducted the bidding following the same procedure as described in the steps i to 1 above.

n) Finally, all winners made the payment and bought the birds from the particular chicken type they won.

\section{Data analysis}

One-way analysis of variance (ANOVA) test was applied to investigate statistical differences between the mean values of auction bids for different chicken types. Paired t-tests were used to determine the impact of providing information on bidding behaviour. A Tobit regression was used to determine the factors that influence the WTP. The Tobit regression model used is given in Eq. 1 and 2. 


$$
\mathbf{Y}^{*}{ }_{\mathrm{ij}}=\beta \mathbf{X}_{\mathrm{ij}}+\varepsilon_{i} \quad ; \varepsilon_{i} \sim \mathbf{N}\left(\mathbf{0}, \sigma^{2}\right)
$$

Where,

$\mathrm{Y}^{*}{ }_{\mathrm{ij}}=$ Latent dependent variable (bid value)

$\mathrm{X}_{\mathrm{ij}}=$ Vector of independent variables

$\beta=$ Vector of parameters

$\varepsilon_{i}=$ Vector of stochastic error term

$$
Y i j=\left\{\begin{array}{c}
Y_{i j}^{*} \text { if } Y^{*}{ }_{i j}>0 \\
0 \text { if } Y^{*}{ }_{i j} \leq 0
\end{array}\right.
$$

Yij $=$ Bid value of $i^{\text {th }}$ bidder for $j^{\text {th }}$ chicken type

\section{RESULTS AND DISCUSSION}

\section{Demographic profile of the participants}

The demographic profiles of the participants in two sites were summarized in Table 4. The majority of the participants were female in both sites $(82 \%$ and $77 \%$ in sites 1 and 2, respectively). The mean age of the participants in site 1 was 44 years and the respective value in site 2 was 46 years. The majority of the participants were educated up to the secondary level $(93.34 \%$ and $81.91 \%$, respectively in sites 1 and 2$)$. The mean monthly household income was Rs. 9367.80 in site 1 and Rs. 11387.10 in site 2. Crop farming followed by livestock farming/fishing were the main livelihood activities of the participants in both sites.

\section{Results of experimental auction}

Summary statistics of bids placed for different chicken types are shown in Table 5. The mean bids were varied across the chicken types and also for same chicken types before and after information.

Data were analyzed using the STATA Statistical package. 
Table 3. Description of variables used in Tobit regression model

\section{\begin{tabular}{l}
\hline Variable name \\
Dependent variable \\
Value of bids \\
Independent variables
\end{tabular}}

Location

Age of the bidders

Education level of the bidders

Monthly household income

Type of chicken

Bidding round

Sex of bidders

Type of primary livelihood activity

\section{Unit Description}

Rupees

The bids placed by bidders for different chicken types

Thirappane $($ site 1$)=1$ Karuwalagaswewa (site 2) $=2$

Years

Primary

Secondary

Tertiary

Categorical variable for the participants of site 1 and 2

Age of the bidders in years

Categorical variable; primary - up

to grade 5 , secondary- grade 5 to

G.C.E A/L, Tertiary -

Degree/Diploma

$\mathrm{D}_{1}=1$ Secondary, Otherwise $=0$

$\mathrm{D}_{2}=1$ Tertiary, Otherwise $=0$

Rupees

Monthly household income

Commercial chicken

Normal village chicken

Categorical variable for different chicken types

Naked neck

Frizzled feathered

Crown chicken

$\mathrm{D}_{1}=1$ Normal village chicken,

Otherwise $=0$

$\mathrm{D}_{2}=1$ Naked neck, Otherwise $=0$

$\mathrm{D}_{3}=1$ Frizzled, Otherwise $=0$

$\mathrm{D}_{4}=1$ Crown, Otherwise $=0$

Round $1=1$

Round $2=2$

Categorical variable for bidding round 1 with no information and round 2 with information

Male $=1$

Female $=2$

Categorical variable for whether the bidder is a male or a female

Crop farming

Categorical variable for the type

Livestock farming/fishing of primary livelihood activity of Government/private the bidders

Labour

$\mathrm{D}_{1}=1$ Crop farming, Otherwise $=0$

Other (retired, self

$\mathrm{D}_{2}=1$ Livestock/fishing,

employed etc.)

$\mathrm{D}_{3}=1$ Government/private

Otherwise $=0$

$\mathrm{D}_{4}=1$ Labour, Otherwise $=0$ 
Table 4. Demographic profile of the participants in two sites

\begin{tabular}{|c|c|c|c|c|c|}
\hline \multirow[t]{2}{*}{ Variable } & & \multicolumn{2}{|l|}{$\begin{array}{l}\text { Thirappane } \\
\text { Site } 1(N=45)\end{array}$} & \multicolumn{2}{|c|}{$\begin{array}{l}\text { Karuwalagaswewa } \\
\text { Site } 2(N=94)\end{array}$} \\
\hline & & $\begin{array}{l}\text { Mean } \\
\text { (SD) }\end{array}$ & $\begin{array}{l}\text { Percen } \\
\text { tage }\end{array}$ & $\begin{array}{l}\text { Mean } \\
\text { (SD) }\end{array}$ & $\begin{array}{l}\text { Percen } \\
\text { tage }\end{array}$ \\
\hline \multirow[t]{2}{*}{ Sex } & Male & & 18 & & 23 \\
\hline & Female & & 82 & & 77 \\
\hline Age & & $\begin{array}{l}44.40 \\
(9.90)\end{array}$ & & $\begin{array}{l}45.84 \\
(11.39)\end{array}$ & \\
\hline \multirow[t]{3}{*}{ Education } & Primary & & 4.44 & & 15.96 \\
\hline & Secondary & & 93.34 & & 81.91 \\
\hline & Tertiary & & 2.22 & & 2.13 \\
\hline $\begin{array}{l}\text { Monthly household } \\
\text { income }\end{array}$ & & $\begin{array}{l}9367.77 \\
(10545.91)\end{array}$ & & $\begin{array}{l}11387.10 \\
(9005.17)\end{array}$ & \\
\hline $\begin{array}{l}\text { Average household } \\
\text { size }\end{array}$ & & $\begin{array}{l}3.57 \\
(1.23)\end{array}$ & & $\begin{array}{l}3.73 \\
(1.32)\end{array}$ & \\
\hline \multirow[t]{5}{*}{ Primary activity } & Crop farming & & 75.55 & & 59.57 \\
\hline & livestock farming /fishing & & 17.78 & & 13.83 \\
\hline & Government/private institute & & 4.45 & & 7.45 \\
\hline & Labour & & 2.22 & & 11.7 \\
\hline & $\begin{array}{l}\text { Other (retired, self employed } \\
\text { etc.) }\end{array}$ & & - & & 7.45 \\
\hline
\end{tabular}

Table 5. Summary statistics of bids by chicken type

\begin{tabular}{llrrrrr}
\hline Bidding round & & \multicolumn{4}{c}{ Chicken types } \\
& & $\begin{array}{c}\text { Commercial } \\
\text { layer }\end{array}$ & $\begin{array}{c}\text { Normal } \\
\text { village } \\
\text { chicken }\end{array}$ & $\begin{array}{c}\text { Naked } \\
\text { neck }\end{array}$ & $\begin{array}{c}\text { Frizzled } \\
\text { feathered }\end{array}$ & $\begin{array}{c}\text { Crown } \\
\text { chicken }\end{array}$ \\
\hline \multirow{1}{c}{ (No } & Mean bid (Rs.) & 149.38 & 132.14 & 161.25 & 232.71 & 197.96 \\
information) & Std. dev & 91.89 & 52.09 & 103.23 & 61.99 & 63.9 \\
& Maximum bid (Rs.) & 520 & 200 & 500 & 400 & 350 \\
& Minimum bid (Rs.) & 12 & 0 & 10 & 100 & 75 \\
(With & Mean (Rs.) & 158.64 & 190.71 & 170.34 & 267.45 & 232.96 \\
information) & Std. dev & 103.34 & 79.01 & 98.56 & 75.79 & 67.64 \\
& Maximum bid (Rs.) & 450 & 450 & 350 & 400 & 350 \\
& Minimum bid (Rs.) & 0 & 0 & 0 & 100 & 75 \\
\hline
\end{tabular}

One-way ANOVA were done on the grouped bids for chicks of different chicken types in bidding round 1 and 2 separately. The results of one-way ANOVA were summarized in Table 6. Results showed that there are significant differences among the bids for chicks of different chicken types. This indicates that farmers' WTP for chicks differ according to the chicken type. Mean bids for chicks of indigenous chicken types were higher than commercial layer chicks in both bidding rounds except for normal village chicken in bidding round 1. In 
bidding round 1, the mean bids for naked neck, frizzled feathered and crown chicken were higher than the mean bids for commercial layer by Rs. 11.86, Rs. 83.32 and Rs. 48.57, respectively. Similarly, in bidding round 2 , the mean bids for normal village chicken, naked neck, frizzled feathered and crown chicken were higher by Rs.32.07, Rs.11.70, Rs. 108.81 and Rs. 74.35, respectively than the mean bid for commercial layer. The results revealed that farmers' WTP for chicks of indigenous chicken types were greater than chicks of commercial layers. Hence, there is an opportunity to develop the indigenous chicks market as a profitable venture which has not yet evolved properly.

Currently the chicks market for indigenous chicken in Sri Lanka is not based on chicken types. However according to the results of the present study, there is an opportunity to develop a market for indigenous chicks based on the chicken types. The highest mean bid was placed for frizzled feathered chicken type in both rounds (Rs. 232.71 in round 1 and Rs. 267.45 in round 2). According to the baseline survey report of GEF-UNEP-ILRI FAnGR Asia-Sri Lanka (2011), availability of frizzled feathered chicken was lower compared to the other indigenous chicken types. The farmers might be tended to bid higher prices for frizzled feathered chicken due to the low availability of this type of chicken. The lowest mean bids were placed to chicks of normal village chicken type (Rs. 132.14) and commercial layer (Rs. 158.64) in round 1 and 2, respectively. The normal village chickenis the most common indigenous chicken type in Sri Lanka (Baseline report GEF-UNEP-ILRI FAnGR Asia-Sri Lanka, 2011). Commonness may be the reason for placing lower bids for normal village chicken type. Bidding round 2 was conducted after providing information on management of commercial versus indigenous chicken and the productivity of each chicken type. The reason behind the lower bidding for chicks of commercial layer in bidding round 2 may be that the farmers realized indigenous chicken are more appropriate for backyard poultry rearing systems than commercial layers after providing the information. Pair-wise comparisons of bids further emphasize that there are significant differences among the farmers' WTP values for different chicken types.

Table 6. Results of one-way ANOVA

\begin{tabular}{|c|c|c|c|c|c|c|c|c|}
\hline \multirow[t]{2}{*}{ Round } & \multicolumn{5}{|c|}{ Mean Bids for chicken types (Rs.) } & \multirow{2}{*}{$\begin{array}{c}\text { F- } \\
\text { value }\end{array}$} & \multirow{2}{*}{$\begin{array}{l}\text { P- } \\
\text { val } \\
\text { ue }\end{array}$} & \multirow{2}{*}{$\begin{array}{c}\text { Significant } \\
\text { differences } \\
\text { between } \\
\text { types }\end{array}$} \\
\hline & $\begin{array}{l}\text { Comme } \\
\text { rcial } \\
\text { layer } \\
\text { (A) }\end{array}$ & $\begin{array}{l}\text { Normal } \\
\text { village } \\
\text { chicken } \\
\text { (B) }\end{array}$ & $\begin{array}{c}\text { Naked } \\
\text { neck } \\
\text { (C) }\end{array}$ & $\begin{array}{c}\text { Frizzled } \\
\text { feathered } \\
\text { (D) }\end{array}$ & $\begin{array}{l}\text { Crown } \\
\text { chicken } \\
\text { (E) }\end{array}$ & & & \\
\hline $\begin{array}{c}1 \\
\text { (No } \\
\text { informatio) }\end{array}$ & $\begin{array}{c}149.39 \\
(91.8)\end{array}$ & $\begin{array}{c}132.14 \\
(52.0)\end{array}$ & $\begin{array}{l}161.25 \\
(103.2)\end{array}$ & $\begin{array}{c}232.71 \\
(61.9)\end{array}$ & $\begin{array}{c}197.96 \\
(63.9)\end{array}$ & 9.08 & 0.0 & $\begin{array}{l}\text { A \& D*** } \\
\text { A \& } \mathrm{E}^{* *} \\
\text { B \& } \mathrm{D}^{* * *} \\
\text { B \& } \mathrm{E}^{* *} \\
\text { C \& } \mathrm{D}^{* * *}\end{array}$ \\
\hline $\begin{array}{c}2 \\
\text { (with } \\
\text { informatio) }\end{array}$ & $\begin{array}{l}158.64 \\
(103.3)\end{array}$ & $\begin{array}{c}190.71 \\
(79.0)\end{array}$ & $\begin{array}{c}170.34 \\
(98.5)\end{array}$ & $\begin{array}{c}267.45 \\
(75.7)\end{array}$ & $\begin{array}{c}232.96 \\
(67.6)\end{array}$ & 11.91 & 0.0 & $\begin{array}{l}\text { A \& D*** } \\
\text { A \& E*** } \\
\text { B \& D*** } \\
\text { C \& D } D^{* * *} \\
\text { C \& E** }\end{array}$ \\
\hline
\end{tabular}

Standard deviations are given in parenthesis.

$* * *$ and $* *$ indicate statistically significant at $1 \%$ and $5 \%$, respectively

Paired t-tests were employed to investigate whether the production and market information had a significant impact on bidding behaviour. The tests were carried out for groups 1, 2, 3 and 4 separately. In each group, comparisons were done separately for two chicken types. For each chicken type, mean bids with and without information were compared. The results 
of paired t-tests are summarized in Table 7. Results showed that mean bids have increased after the exposure of farmers to relevant information except for commercial layer in group 4. However, for indigenous chicken types statistical differences $(\mathrm{p}<0.05)$ were found for normal village chicken, frizzled feathered and crown chicken. This can be due to two reasons. One is the positive impact of information. That is farmers might have realized that indigenous chicken are more appropriate for backyard rearing systems having exposed to the relevant information. The second reason is that the participants have understood the auction mechanism better than the first round. No significant differences were found for commercial layer, except in group 1. There is a well-established market for commercial layer chicks in the country. Hence, most of the famers are aware about the market prices of commercial layer chicks. This may be the reason for not showing any influence of information on WTP values for commercial layers.

Table 7. Results of paired t- tests

\begin{tabular}{|c|c|c|c|c|c|c|}
\hline \multirow[t]{2}{*}{ Group } & \multirow[t]{2}{*}{ Chicken types } & \multirow[t]{2}{*}{$\mathbf{N}$} & \multicolumn{2}{|c|}{ Mean bids (Rs.) } & \multirow{2}{*}{$\begin{array}{l}\text { p- } \\
\text { value }\end{array}$} & \multirow[t]{2}{*}{$\mathrm{t}$-value } \\
\hline & & & $\begin{array}{l}\text { Round 1 } \\
\text { (No } \\
\text { information) }\end{array}$ & $\begin{array}{l}\text { Round } 2 \\
\text { (With } \\
\text { information) }\end{array}$ & & \\
\hline \multirow[t]{2}{*}{1} & Commercial layer & 28 & 111.43 & 145.36 & 0.038 & $2.18 * *$ \\
\hline & $\begin{array}{l}\text { Normal Village } \\
\text { chicken }\end{array}$ & 28 & 132.14 & 190.71 & 0.004 & $4.08^{* * *}$ \\
\hline \multirow[t]{2}{*}{2} & Commercial layer & 44 & 134.48 & 146.50 & 0.498 & 0.68 \\
\hline & Naked neck & 44 & 161.25 & 170.34 & 0.599 & 0.52 \\
\hline \multirow[t]{2}{*}{3} & Commercial layer & 35 & 156.94 & 159.89 & 0.878 & 0.15 \\
\hline & Frizzled feathered & 35 & 232.71 & 267.46 & 0.022 & $2.40 * *$ \\
\hline \multirow[t]{2}{*}{4} & Commercial layer & 32 & 194.84 & 185.62 & 0.531 & 0.63 \\
\hline & Crown chicken & 32 & 197.99 & 232.97 & 0.010 & $2.71 * * *$ \\
\hline
\end{tabular}

$* * *$ and $* *$ indicate statistically significant at $1 \%$ and $5 \%$, respectively

A Tobit model was estimated to identify the factors that influence the bids in this study. A Tobit model was particularly employed because zero bids have been placed by several participants who were not willing to buy chicks of some chicken types. The Tobit regression results (Table 8) revealed that the farmers' WTP for chicks is significantly influenced by age of the bidder, chicken type, bidding round and the primary livelihood activity of the bidder. Age showed a negative relationship with farmers' ETP for chicks. Older farmers place slightly lower bids. Farmers' WTP were high by Rs. 102.78 and Rs. 62.56, respectively for frizzled feathered and crown chicken compared to commercial layer chick. These results also confirmed that there is a potential to expand indigenous chick market because farmers are willing to pay higher prices for indigenous chicks than commercial chicks. In bidding round 2 , the bid value has increased by Rs. 17.25 compared to bidding round 1 . This is consistent with results of paired t-tests which revealed that providing relevant information has a positive impact on bidding behaviour. Primary livelihood activity of the participants influences the willingness to pay. Bidders who work in government/private institutes have placed significantly higher bids compared to the bidder in "other" (self-employed, retired) 
category. The purchasing power might be higher in the bidders who are working in government/private institutes than the bidders in other categories of work. Therefore, they might tend to pay more than others for buying the chicken they want. However, location, level of education, monthly family income and the sex of the bidder did not show any significant influence on WTP.

Table 8. Results of Tobit regression

\begin{tabular}{lccc}
\hline Variable & Coefficient & Std. Err & t value \\
\hline Constant & 202.78 & 26.83 & 7.56 \\
Location & -6.182 & 9.12 & -0.68 \\
Age & $-1.03^{* * *}$ & 0.38 & -2.71 \\
Education & & & \\
$\quad$ Secondary & -17.75 & 12.24 & -1.45 \\
$\quad$ Tertiary & -13.61 & 33.67 & -0.40 \\
Monthly family income & -0.00003 & 0.0005 & -0.06 \\
Chicken type & & & \\
$\quad$ Normal village chicken & 8.60 & 13.62 & 0.63 \\
$\quad$ Naked neck & 14.59 & 11.23 & 1.30 \\
$\quad$ Frizzled feathered & $102.78^{* * *}$ & 12.47 & 8.24 \\
$\quad$ Crown chicken & $62.56^{* * *}$ & 13.04 & 4.80 \\
Bidding round & $17.25^{* *}$ & 7.69 & 2.24 \\
Sex of bidder & 14.51 & 10.50 & 1.38 \\
Primary activity & & & \\
$\quad$ Crop farming & -5.41 & 14.82 & -0.37 \\
$\quad$ Livestock farming/fishing & 15.23 & 17.11 & 0.89 \\
$\quad$ Government/private institute & $47.34^{* *}$ & 23.42 & 2.02 \\
$\quad$ Labour & 12.02 & 24.62 & 0.49 \\
& & & \\
\hline Chi square & 104.81 & & \\
Number of observations & 548 & &
\end{tabular}

\section{CONCLUSIONS}

Farmers were willing to pay more for buying indigenous chicks than commercial chicks. Farmers' preferences for buying chicks differ according to the type of the chicken. Also production and market information had a positive impact on bidding behaviour. Further, the farmers' willingness to pay for chicks is significantly influenced by the age of the bidder, chicken type, bidding round (with and without information) and the primary livelihood activity of the bidders. 
Findings of the study suggest that there is a potential to expand the indigenous poultry sector in the country. Indigenous chicks market has the potential to sell chicks differentiated by chicken type and this will also help farmers to buy chicks as they preferred. Improving the farmers' awareness about the advantages and the suitability of indigenous chicken for backyard poultry will be helpful in expanding the backyard poultry sector.

\section{ACKNOWLEDGEMENT}

The authors wish to acknowledge the GEF-UNEP-ILRI FAnGR Asia project for facilitating the study.

\section{REFERENCES}

Becker, G.M., DeGroot, M.H., Marschak.,J. (1964). Measuring utility by a single-response sequential method. Behavioural Science, 9, 226 - 232.

Coppinger, V.M., Smith, V.L., Titus, J.A. (1980). Incentives and behaviour in English, Dutch, and Sealed-bid auctions.Economic inquiry, 43, 1 - 22.

Das, S.C., Chowdhury, S.D., Khatun, M.A., Nishibori, M., Isoben, N., Yoshimuray, Y. (2008). Poultry production profile and expected future projection in Bangladesh.

World's Poultry Science Journal. 64, 99 - 118.

FAnGR Asia Project (2011). Baseline survey data on indigenous chicken and pigs in Sri Lanka.UNEP-GEF-ILRI FAnGR Asia project, Sri Lanka. (available at http://fangrsl.org)

Gondwe, T., Wollny, C. (2007). Local chicken production system in Malawi: Household flock structure, dynamics, management and health. Tropical Animal Health and Production. 39, $103-113$.

Lusk, J.L., Shogren, J.F. (2007). Experimental Auctions: Methods and Applications in Economic and Marketing research. Cambridge Universal Press, Cambridge.

Mlozi, M.R.S., Kakengi, A.V.M., Minga, U.M., Mtambo, A.M., Olsen, J.E. (2003).

Marketing of free range local chickens in Morogoro and Kilosa urban markets,Tanzania.

Livestock Research for Rural Development, 15, 2.

Scoones, I. ( 1992). The economic value of livestock in the communal areas of southern Zimbabwe. Agricultural Systems. 39, 339 - 359

Vickrey, W. (1961). Counter speculation, auctions and competitive sealed tenders. Journal of finance, $16,8-37$. 


\section{APPENDICES}

\section{Appendix A}

Bidding instructions

- Do not talk to other participants for the entire duration of the auction

- Do not show your bid to any other participant

- Bid truthfully because over bidding will be end up with paying more money than what you are really willing to pay and lower bidding will reduce your chance to win

- You can place zero bids for any type of chicken if you are not interest in buying it

\section{Appendix B}

Production and market information of indigenous and commercial chicken

\begin{tabular}{llllll}
\hline & \multicolumn{3}{c}{ Indigenous chicken types } & \\
\cline { 2 - 5 } & $\begin{array}{c}\text { Normal } \\
\text { village } \\
\text { chicken }\end{array}$ & $\begin{array}{c}\text { Naked } \\
\text { neck }\end{array}$ & $\begin{array}{c}\text { Frizzled } \\
\text { feathered }\end{array}$ & $\begin{array}{c}\text { Crown } \\
\text { chicke } \\
\text { n }\end{array}$ & $\begin{array}{c}\text { Commercial } \\
\text { chicken }\end{array}$ \\
\hline $\begin{array}{l}\text { Age at first laying } \\
\text { (months) }\end{array}$ & 5.78 & 7.05 & N/A & 7.30 & 5 \\
Annual egg production & 60 & 56 & N/A & 97 & 300 \\
Mature body weight (Kg) & 1.3 & 1.27 & N/A & 2.13 & 3 \\
Rearing systems & Extensive & & & & Intensive \\
Feeding practices & Scavenging with low cost & supplementary feeds & $\begin{array}{l}\text { Commercial } \\
\text { feeds }\end{array}$ \\
Health care practices & Not required & & & & Vaccination \\
Initial cost & Low & & & High \\
Total cost & Low & & High \\
Price of eggs (Rs./egg) & Rs. 20.00-25.00 & & Rs. 14.00 \\
Price of meat (Rs./kg) & Rs. 450.00-600.00 & & Rs.380.00 \\
\hline
\end{tabular}

Source: Baseline survey report, GEF-UNEP-ILRI FAnGR Asia Project, 2011

N/A: Data not available

\section{Appendix C}

Different chicken types displayed in cages

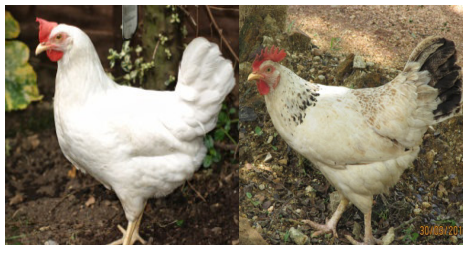

A

B

Commercial chicken
Normal village chicken

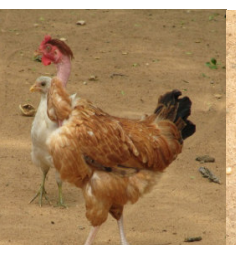

C

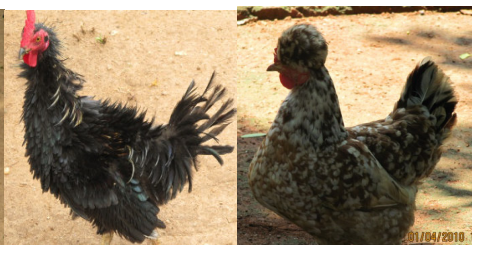

D
E

Frizzled

Crown

feathered 